\title{
Facile Synthesis of Poly(DMAEMA-co-MPS)-coated Porous Silica Nanocarriers as Dual-targeting Drug Delivery Platform: Experimental and Biological Investigations
}

\author{
Mohammad Hegazy, ${ }^{1,2, \star}$ Pei Zhou, ${ }^{3}$ Guangyu Wu, ${ }^{4}$ Nadia Taloub, ${ }^{1,5}$ \\ Muhammad Zayed, ${ }^{6}$ Xin Huang ${ }^{1, *}$ and Yudong Huang ${ }^{1, *}$ \\ ${ }^{1}$ MIIT Key Laboratory of Critical Materials Technology for New Energy Conversion and Storage, Key Laboratory \\ of Microsystems and Microstructures Manufacturing, School of Chemistry and Chemical Engineering, \\ Harbin Institute of Technology, Harbin 150001, China \\ ${ }^{2}$ Department of Polymer Chemistry, Faculty of Science, Menoufia University, Shebin El-Kom 32511, Egypt \\ ${ }^{3}$ School of Environmental and Municipal Engineering, North China University of Water Resources and Electric Power, \\ Zhengzhou 450011, China \\ ${ }^{4}$ College of Biology and the Environment, Co-Innovation Center for the Sustainable Forestry in Southern China, \\ Nanjing Forestry University, Nanjing, Jiangsu 210037, China \\ ${ }^{5}$ LIPE Laboratory, University of Constantine 3, 25000 Constantine, Algeria \\ ${ }^{6}$ Botany and Microbiology Department, Menoufia University, Shebin El-Kom, 32511, Egypt
}

*Corresponding author:E-mail: dr_hegazy2000@yahoo.com; xinhuang@hit.edu.cn; huangyd@hit.edu.cn

Received: 07-12-2019

\begin{abstract}
Inorganic structures with functionalized polymers play essential roles in diverse biological trends. Herein, thermal and $\mathrm{CO}_{2}$ dual-stimuli nanomaterials composed of mesoporous silica nanoparticles (MSN) anchored with two grafted copolymers: poly(3-methacryloxypropyltrimethoxysilane) "PMPS" \& poly(N,N-dimethylaminoethyl methacrylate) "PDMAEMA" were synthesized via one-step reaction and characterized by BET as well as BJH methods to estimate pore sizes, pore volumes, and surface areas. The smart PDMAEMA acted as an active gatekeeper to adjust the loading or in vitro release processes of a fungicidal drug-loaded inside the mesopores by altering temperature or $\mathrm{CO}_{2}$ of the tested environment. Furthermore, treating the nanomaterials by $\mathrm{CO}_{2}$ for a few minutes was found to have a bactericidal effect with promising results as indicated by the disk diffusion technique. In general, the positive biological activity against selected strains of bacteria and fungi indicates that these particles may be helpful for engineering more efficient antifungal or antibacterial agents for pharmaceutical applications.
\end{abstract}

Keywords: $\mathrm{CO}_{2}$-responsive release, thermal-triggered release, biopolymeric materials, antimicrobial agents

\section{Introduction}

Over the past two decades, smart polymeric materials have been exploited for versatile applications e.g. ion absorbance capacity, ${ }^{1}$ wastewater treatment, ${ }^{2}$ cargo delivery systems, ${ }^{3}$ photodynamic or photothermal effects, ${ }^{4}$ and enhancing the mechanical properties as well as the interfacial performance of specific fibers. ${ }^{5,6} \mathrm{~A}$ famous ex- ample is MSN which have been used widely as drug carriers in biomedical technologies, thanks to several merits e.g. biocompatibility, easiness of surface-modification, and controllable mesopore sizes. ${ }^{7}$ PDMAEMA was applied as a $\mathrm{CO}_{2}$ responsive polymer in aqueous solutions as a result of protonation of the tertiary amine group which can also deprotonate reversibly by $\mathrm{N}_{2}$ stimulation, i.e. swelling-shrinking effect. ${ }^{8}$ Furthermore, this smart 
polymer showed pretty good thermo-responsiveness, as it can form coil-to-globule states by changing temperatures degrees and showed a lower critical solution temperature (LCST) in aqueous solutions, ${ }^{9}$ which is a similar character to the well-known thermosensitive poly( $\mathrm{N}$-isopropylacrylamide) (PNIPAAm). ${ }^{10,11}$ More interestingly, quaternization of terminal amino groups of PDMAEMA had promising antimicrobial activity against some bacterial strains. ${ }^{12}$

Because of the possible applications in various promising areas including material science and life science, this study aims to synthesize and characterize pharmaceutical nanocontainers with dual-sensitive character to release the loaded cargos with a response to $\mathrm{CO}_{2}$ or temperature or both together, followed by biological evaluation against microbial strains as illustrated in Scheme 1. We exploited the alkoxysilane moiety of silicon derivative monomer 3-methacryloxypropyltrimethoxysilane (MPS) to link it (through a condensation reaction) with silanols surface of MSN from one side. In contrast, the other side (active double bond) was polymerized simultaneously with N,N-dimethylaminoethyl methacrylate (DMAEMA) monomer via thermal polymerization using AIBN as azo initiator. $^{13,14}$ The growing PDMAEMA onto the MSN surface was used as a cap to maintain or trigger anidulafungin, which utilized as a model antifungal drug. The release behavior of the cargo was investigated by the two mentioned responses and tested against some microorganisms to evaluate the biological activity. The advantages of this construction are not only for the simple synthesis via a onestep experiment, but also lie for obtaining high drug load- ing capacity, effective response for thermo- or $\mathrm{CO}_{2}$-stimuli and the potential application as antifungal or antibacterial agents, especially after converting PDMAEMA into its cationic form.

\section{Materials and Characterization Techniques}

The chemicals and reagents were purchased with analytical grade via Sigma-Aldrich. The specific surface areas and mesoporous structures were obtained through $\mathrm{N}_{2}$ adsorption-desorption isotherms. The cloud point for a given polymeric material solution was chosen as the corresponding inflection point of "the transmittance versus temperature curve". The LCST results of the aqueous material solutions were determined at a $50 \%$ decrease of the optical transmittance, through measuring the wavelength at $500 \mathrm{~nm}$ using a UV-visible spectrophotometer (Shimadzu UV-1700). The temperature degrees of the sample cells were controlled thermostatically by using an exterior constant temperature bath. Zeta potential analysis for polymeric material solutions ( $\mathrm{pH} 6.8,5.0 \mathrm{mM}$ buffer PBS, $0.2 \mathrm{mg} / \mathrm{mL}$ material sample) was tested by using a ZETASIZER (Malvern Instruments, Britain) at $25^{\circ} \mathrm{C}$. Both loading and releasing contents of anidulafungin drug were studied by UV-Vis spectrophotometry at $\lambda$ max of $303 \mathrm{~nm}$. Random isolates from Escherichia coli (E.coli, gram-negative bacteria) as well as Candida albicans ( $C$. albicans, fungi) were obtained from the College of Life Science, Northeast Forestry University, Harbin, China.

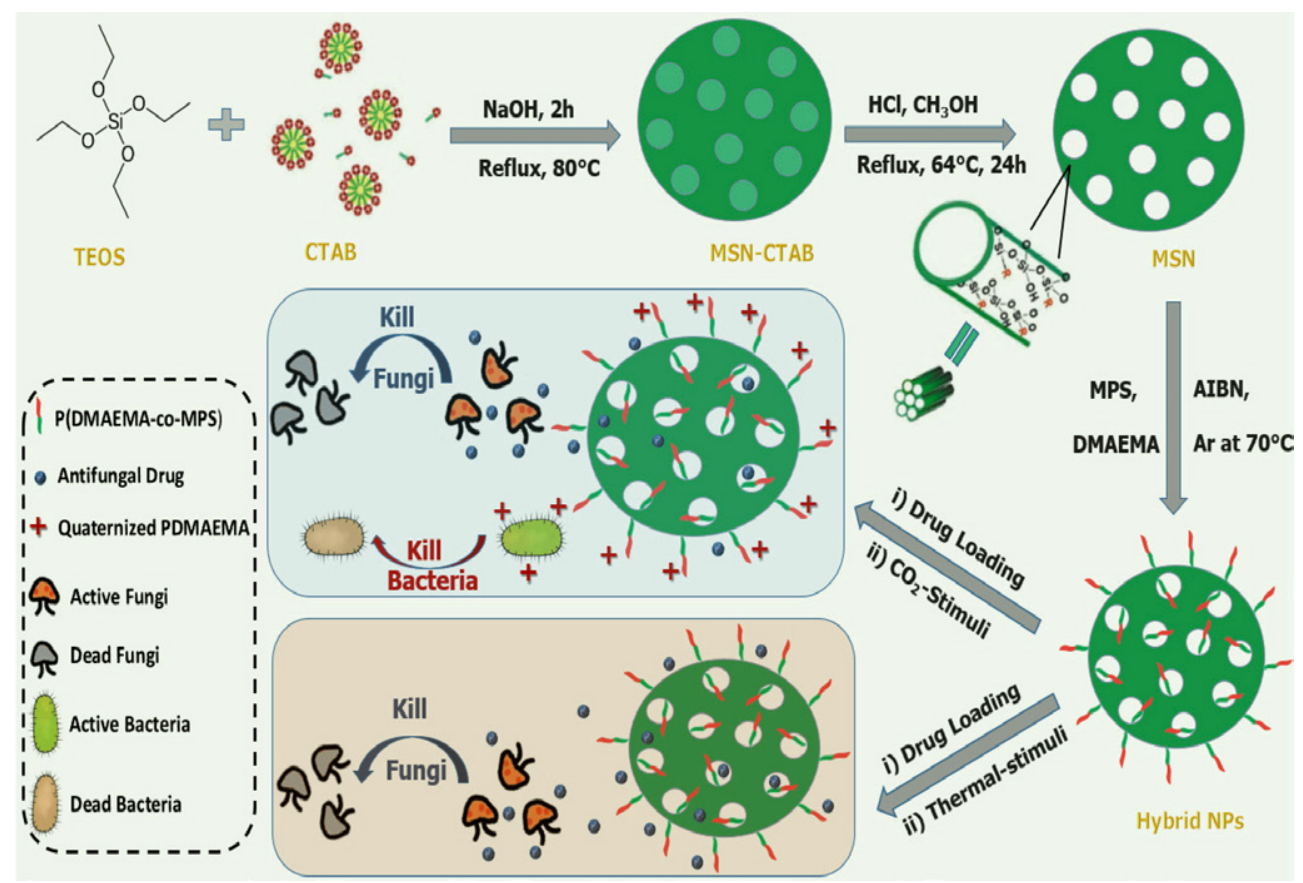

Scheme 1. Schematic illustration of MSN/P(MPS-co-DMAEMA) generation followed by drug loading, then $\mathrm{CO}_{2}$ and hyperthermia-induced release through the dual-functional biomedical platform. 
The culture medium was nutrient agar (NA) which prepared by adding agar ( $20 \mathrm{gm})$, beef extract ( $3 \mathrm{gm})$, peptone $(5 \mathrm{gm})$ and sodium chloride $(5 \mathrm{gm})$ then completed to one liter of deionized water.

\section{Methods}

MSN/P(MPS-co-DMAEMA) nanocarriers were prepared by established polymerization method, ${ }^{15}$ and then loaded with anidulafungin drug after several purifications according to Rahoui et al. ${ }^{16}$ The loading content of the drug was estimated from UV-Vis spectra via Eq. (1).
(MPS-co-DMAEMA) nanocarriers were represented in Fig. 1.

Both MSN and MSN/P(MPS-co-DMAEMA) nanocarriers were synthesized according to Scheme 1 , then characterized by $\mathrm{N}_{2}$ sorption isotherms (Fig. 2), using BET and $\mathrm{BJH}$ methods. For both materials, the isotherms were of type IV, which suggesting the mesoporous nature ${ }^{19}$ as indicated in Fig. 2A. The high surface area of $705 \mathrm{~m}^{2} \mathrm{~g}^{-1}$ for MSN had decreased considerably to $257 \mathrm{~m}^{2} \mathrm{~g}^{-1}$ after coating with the copolymer layer to obtain MSN/P(MPS- co-DMAEMA) (see Table 1), which matching well with similar studies. ${ }^{20,21}$ Similarly and from pore size distribution curves (Fig. $2 \mathrm{~B})$ and the same Table, there was a decrease in the pore

$$
\text { Loading content }(\%)=\frac{\text { the initial amount of drug }- \text { the supernatant free amount of drug }}{\text { the weight of loaded drug nanocarriers }} \times 100
$$

On contrast, in vitro drug release experiments were tested in physiological saline solution (PSS) and estimated according to Eq. (2) at different periods (from $1 \mathrm{~h}$ to 24h). ${ }^{7,16}$ The release behavior in PSS (100 mM) using dialysis membrane (molecular weight cut-off: $8000-14000$ $\mathrm{Da}$ ) were calculated by detecting the corresponding absorbance peak of anidulafungin at $303 \mathrm{~nm}$ using different environments including; (i) temperature lower and higher LCST of PDMAEMA (i.e. $25^{\circ} \mathrm{C} \& 45^{\circ} \mathrm{C}$ ) and (ii) bubbling with $\mathrm{CO}_{2}$ for $10 \mathrm{~min}$ at the two mentioned temperatures. volume (from 0.66 to $0.51 \mathrm{~mL} / \mathrm{g}$ ) along with the mean pore diameter (from 8.82 to $6.53 \mathrm{~nm}$ ), when going from MSN to MSN/P(MPS-co-DMAEMA). The maintained large pore volumeandhighsurfaceareaforMSN/P(MPS-co-DMAEMA nanocarriers, refers to that their mesopores have not been blocked after anchoring both PMPS \& PDMAEMA on the silica surface, and consequently have the opportunity to carry the drug in the next step.

The $\mathrm{pH}$-dependent electro-kinetic characterizations were used to demonstrate the effect of $\mathrm{pH}$ changes on the

$$
\text { Releasing content }(\%)=\frac{\text { the amount of drug in the release medium }}{\text { the amount of loaded drug into nanocarriers }} \times 100
$$

The antimicrobial activity for the nanocarriers containing anidulafungin (NCA) was tested (after the releasing process with the two stimuli) using the well diffusion technique. The inoculum density in the chosen NA plate was $10^{8}$ $\mathrm{CFU} \cdot \mathrm{ml}^{-1}$, which related to the $0.5 \mathrm{McF}$ arland turbidity scale. ${ }^{17}$ The seeded plates were dried in the incubator at 36 ${ }^{\circ} \mathrm{C}$ for $25 \mathrm{~min}$. A borer of cork with $7 \mathrm{ml}$ diameter was applied to cut uniform wells onto the inoculated agar surface, then around $100 \mu \mathrm{l}$ of every sample $(20 \mathrm{mg} / \mathrm{ml})$ was added to the well. Free anidulafungin and tetracycline were used (with the same concentration as NCA) as the positive control for antifungal and antibacterial activities, respectively. Deionized water and filter paper were used as the negative control (around $100 \mu \mathrm{l}$ of the solvent). The plates were accordingly incubated for one day at the normal body temperature (37 ${ }^{\circ} \mathrm{C}$ ). By the end of incubation time, the biological activity was tested through inhibition zones in millimeters. ${ }^{18}$

\section{Results and Discussion}

The corresponding chemical structures of MPS monomer, DMAEMA monomer, MSN and MSN/P

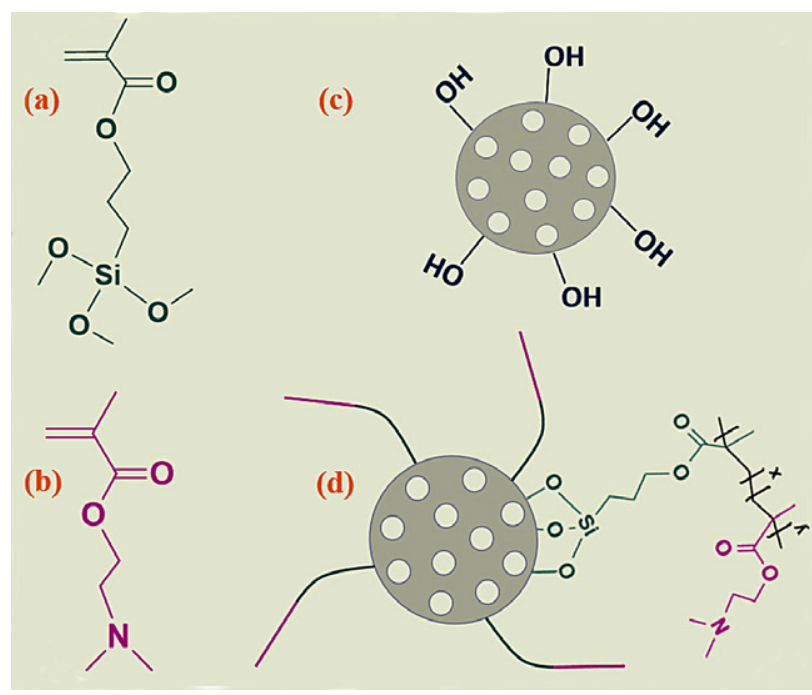

Fig. 1. Chemical structures of (a) MPS monomer, (b) DMAEMA monomer, (c) MSN and (d) MSN/P(MPS-co-DMAEMA) nanocarriers.

obtained nanocarrier solutions, and to strengthen the understanding of the process and its usefulness. As shown in 

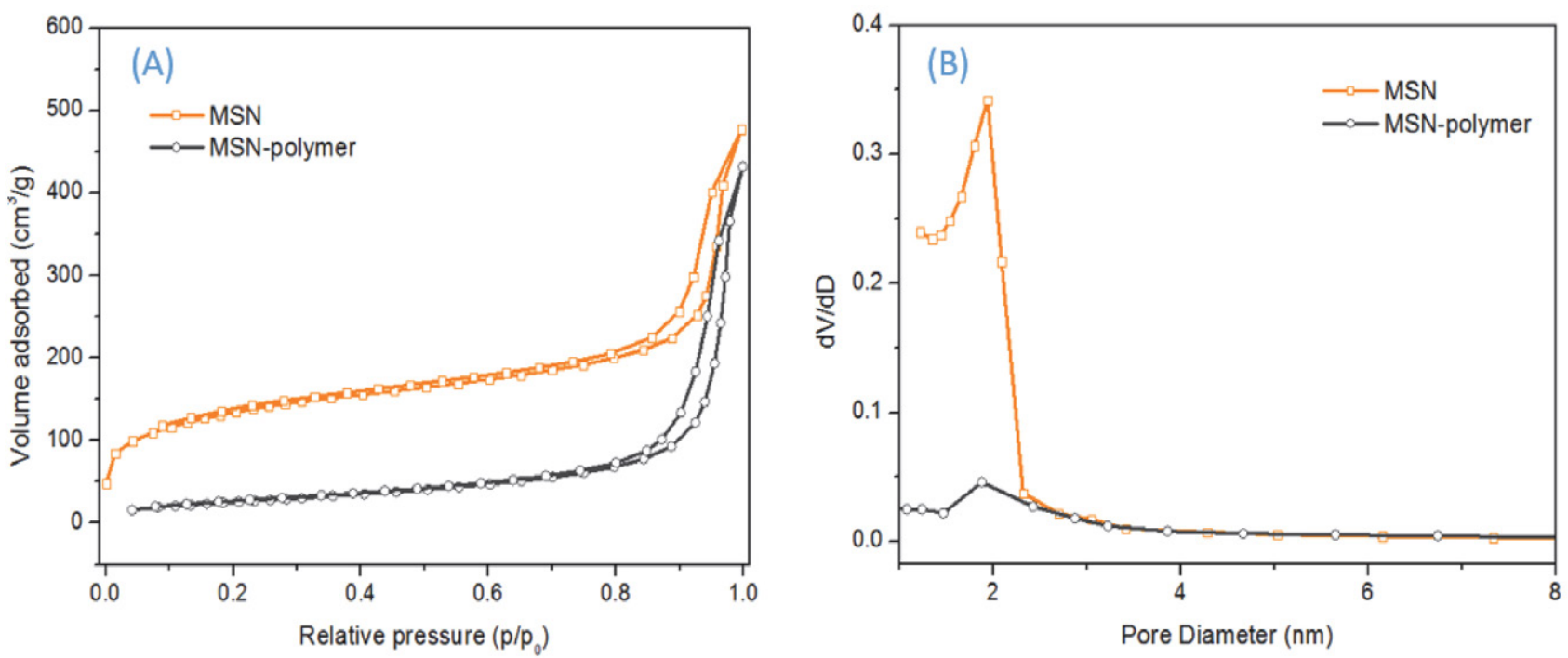

Fig. 2. (A) $\mathrm{N}_{2}$ adsorption-desorption isotherms and (B) pore size distribution curves for MSN and MSN/P(MPS-co-DMAEMA).

Table 1. Structure parameters of MSN and MSN/P(MPS-co -DMAEMA) derived from nitrogen sorption.

\begin{tabular}{lccc}
\hline Samples & BET surface area $\left(\mathbf{m}^{2} / \mathbf{g}\right)$ & Pore volume $(\mathbf{m L} / \mathbf{g})$ & Mean pore diameter $(\mathbf{n m})$ \\
\hline MSN & 705 & 0.66 & 8.82 \\
MSN/P(MPS-co-DMAEMA) & 257 & 0.51 & 6.53 \\
\hline
\end{tabular}

Fig. 3, the apparent zeta-potential $(\zeta)$ decreases notably with the $\mathrm{pH}$ increasing, which perhaps due to protonation of tertiary-amine groups (involved within PDMAEMA backbones) by acidic media, therefore, $\zeta$ has high positive values with low $\mathrm{pH}$ values and vice versa. The critical $\mathrm{pH}$ for PDMAEMA chains needed to plug the pores of the prepared nanocarriers was measured to be $\mathrm{pH} 7.2$ which is lower than 7.4 value (human blood medium). Thus, one can conclude that in case this system is used as a smart drug delivery nanocarrier, the release of any encapsulat-

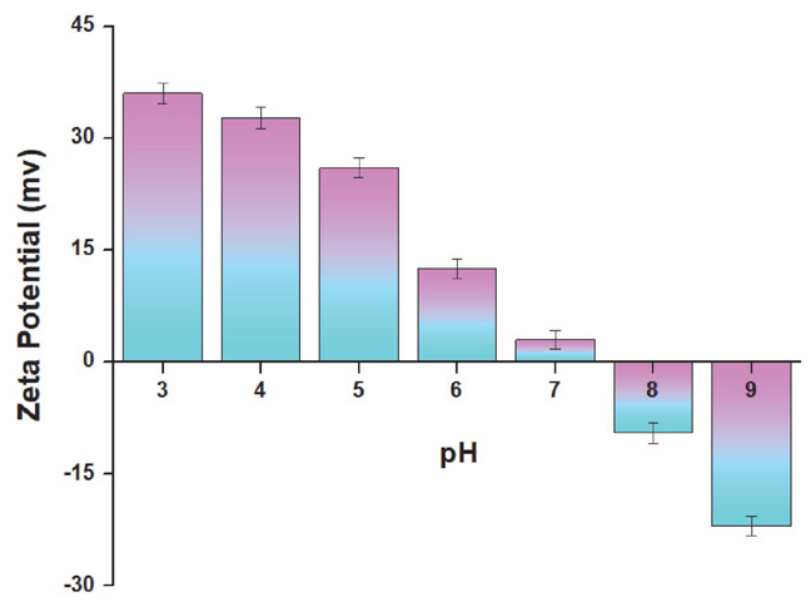

Fig. 3. Apparent zeta-potential (ל) measurements for MSN/P(MPSco-DMAEMA) nanocarriers determined from $\mathrm{pH}$-dependent experiments. ed-drug from MSN/P(MPS-co-DMAEMA) can only be noticed after reaching the desired pathological organs, where the $\mathrm{pH}$ values are slightly acidic (e.g. treatment of $\mathrm{CO}_{2}$ gas in our study here).

It is widely known that thermo-sensitive polymers/ copolymers can display phase separation by increasing their temperature degrees above the lower critical solution temperature (LCST). Since PDMAEMA is a typical weak polyelectrolyte and its $\mathrm{pKa}$ value is 7.0-7.5 (with exhibiting an LCST of $40-50^{\circ} \mathrm{C}$ in the aqueous solutions ${ }^{22}$ ), we tested LCST of the obtained MSN/P(MPS-co-DMAEMA) nanocarriers in a $\mathrm{pH}$-controlled environment because the LCST is pH-dependent and the solubility of $\mathrm{CO}_{2}$ is temperature-dependent.

It is expected that MSN/P(MPS-co-DMAEMA) nanomaterials are $\mathrm{pH}$-responsive as similar to PDMAEMA due to the presence of terminal dimethylamino groups. The $\mathrm{pH}$-sensitive properties of these polymeric materials are shown in Fig. 4. One can notice the transmittance character (for aqueous solutions of such materials) against temperature degrees at different $\mathrm{pH}$ values, whereas the LCST is indicated at a $\mathrm{pH}$ range beginning from 3.35 to 10.92 . It is clear that the aqueous solutions of MSN/P(MPS-co-DMAEMA) are soluble in low $\mathrm{pH}$ environments, such as $3.35 \& 6.42$, and no LCST is obtained within a temperature range of $20-60{ }^{\circ} \mathrm{C}$ for theses environments. This perhaps is due to the occurrence of stable polymeric nanomaterials that formed at low $\mathrm{pH}$ and yielding protonated PDMAEMA side chains in the 


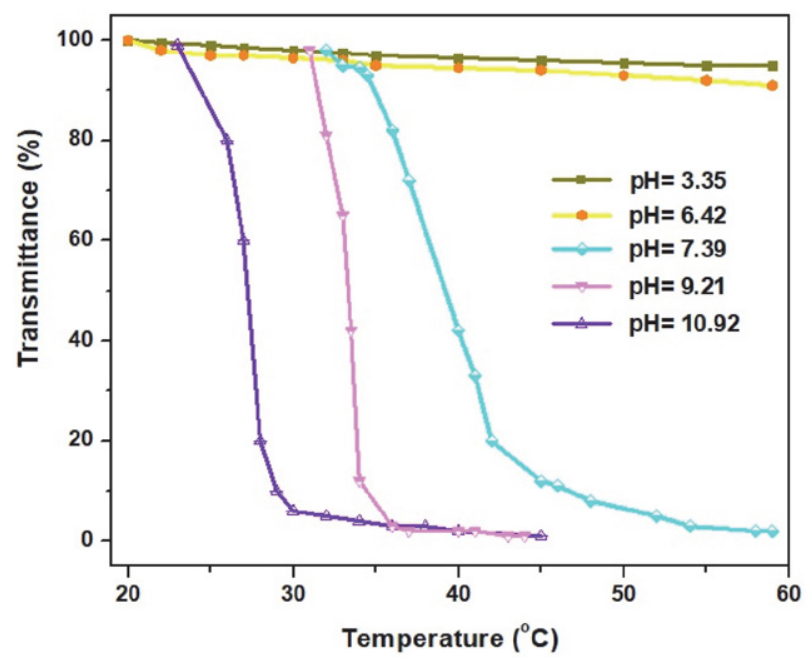

Fig. 4. Transmittance for aqueous solutions of MSN/P(MPS-coDMAEMA) as a function of temperature degrees at various $\mathrm{pH}$ values.

outer shell of the nanomaterials, leading to an increase in the electrostatic repulsion force and consequently preventing the phase separation. ${ }^{23}$ By contrast, the LCST of MSN/P(MPS-co- DMAEMA) is noticed at $\mathrm{pH} 7.39$. Moreover, the cloud temperature of the polymeric nanomaterials decreases gradually by raising the $\mathrm{pH}$ from 7.39 to 10.92 , which is similar to the situation of LCST for PDMAEMA homopolymer that discussed by Plamper et al. ${ }^{24}$

For drug encapsulation studies, anidulafungin was chosen as a model antifungal agent, especially for the treatment of candidemia caused by Candida albicans yeast. The loading content (\%) was calculated by UV-Vis spectrophotometry at $\lambda \max$ of $303 \mathrm{~nm}$ according to Eq. (1) and it was $17.9 \pm 0.7 \%$, which is still higher than most surface-modified MSN previous studies (lower than 10\%). This could be attributed to the hydrogen bonds and strong electrostatic interactions between the drug and nanocarriers.

The triggered release of anidulafungin from NCA was tested by the dialysis method in PSS, according to Eq. (2) under the following environments: (i) $25^{\circ} \mathrm{C}$, (ii) $45^{\circ} \mathrm{C}$, (iii) $25^{\circ} \mathrm{C}$ \& bubbling with $\mathrm{CO}_{2}$ for $10 \mathrm{~min}$ and (iv) $45{ }^{\circ} \mathrm{C} \&$ bubbling with $\mathrm{CO}_{2}$ for $10 \mathrm{~min}$. The results demonstrated that the extended copolymer could perform as a smart gatekeeper for this system according to $\mathrm{CO}_{2}$ or temperature changes. For the gas-response, the extended PDMAEMA is hydrophobic at neutral or alkaline $\mathrm{pH}$ values with collapsed uncharged chains, while it can convert into the weak cationic character in acidic medium with water-soluble, protonated and extended chains (i.e. after treated with $\mathrm{CO}_{2}$ gas). ${ }^{25}$ On the other hand, the releasing of anidulafungin at hyperthermia state could be related to thermo-responsive features of the PDMAEMA segments. When the temperature increased (above LCST), the extended PDMAEMA units would shrink to the globular structure due to the weak- ening or breaking of hydrogen bonds, which resulting in collapsed PDMAEMA chains. ${ }^{26}$

The release process of the chosen antifungal drug at the four mentioned conditions was indicated in Fig. 5. About $13 \%$ of conjugated anidulafungin was only released from the NCA after incubation for 36 hours at room temperature, indicating that many anidulafungin molecules were still covalently incorporated inside the nanocarriers without significant release. Therefore, the release level of anidulafungin is low, which further indicates the stability of this polymeric material at room temperature. Also, there is a hydrophobic interaction between anidulafungin and PMPS chains and at the same time the anidulafungin has interactions with PDMAEMA layers in aqueous media (thanks to its unique chemical constitution).

On the other hand, the released amount of the encapsulated payload reached $25 \%$ after bubbling with $\mathrm{CO}_{2}$ for $10 \mathrm{~min}$ at room temperature and during the same number of hours, indicating that, such carbon dioxide treatment for these polymeric materials can induce the programmed release in a successful way.

Subsequently, at $45^{\circ} \mathrm{C}$ (which is above the LCST), the release process increased dramatically to $35 \%$ within only $10 \mathrm{~h}$ and reached $63 \%$ after $36 \mathrm{~h}$. This substantial increase could be due to the copolymer layer underwent a coil-to globule change and shrank into a compact mass, which allowing pores opening and showing the significant release of the loaded drug. This situation illustrates a good agreement with most known thermoresponsive polymeric-nanomaterials which can keep their cargos at room temperature, and then deliver them within the locally heated diseased sites $\left(\sim 40-42^{\circ} \mathrm{C}\right)$.

Moreover, the release behavior of the drug at $45^{\circ} \mathrm{C}$ after bubbling with $\mathrm{CO}_{2}$ for 10 min was noticed to yield around $21 \%$ after $10 \mathrm{~h} \& 42 \%$ after $36 \mathrm{~h}$, which was lower than the corresponding release at $45^{\circ} \mathrm{C}$ alone without $\mathrm{CO}_{2}$ bubbling. However, the release condition of $45^{\circ} \mathrm{C}$ with

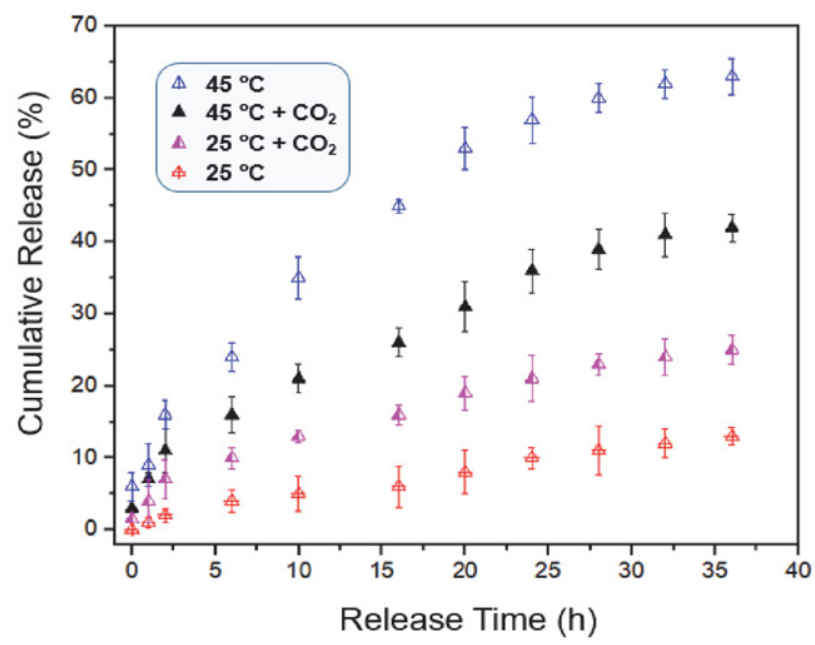

Fig. 5. Controlled release of anidulafungin from NCA at four different conditions. 
$\mathrm{CO}_{2}$ was still higher than the other previous two conditions $\left(25^{\circ} \mathrm{C}\right.$ without $\mathrm{CO}_{2} \& 25^{\circ} \mathrm{C}$ with $\left.\mathrm{CO}_{2}\right)$. This could be attributed to the increase of thermo-motions at elevated temperature enhanced the diffusion of anidulafungin from the expanded nanoparticles.

After the releasing processes via dual stimuli from $\mathrm{NCA}$, we evaluated the biological activity through antimicrobial screening using two organisms (E.coli, \& C. albicans) according to Table 2. Free anidulafungin and tetracycline were used as the positive control for the antifungal and antibacterial properties, respectively. The results showed that NCA did not express the essential antimicrobial impact on these microorganisms except an exceedingly weak impact on C. albicans, which perhaps due to the minimal leakage of anidulafungin from NCA at room temperature (entry 1 in Table 2). Bubbling with $\mathrm{CO}_{2}$ for $10 \mathrm{~min}$ at this room temperature (single $\mathrm{CO}_{2}$ stimulus, entry 2 in Table 2), showed a moderate antifungal effect against $C$. albicans, but a very strong one against E. coli, which could be attributed to formation of ionene polymers (cationic polymers include positive nitrogen or phosphor in their backbones) after reacting with $\mathrm{CO}_{2}$ gas. This result is in a good agreement with recent studies, which proved that the cationic PDMAEMA ${ }^{+}$has a strong bactericidal effect against $E$. coli and some other bacterial strains. $^{12,27}$

On the other hand, upon heating to $45^{\circ} \mathrm{C}$ (temperature stimulus alone), no antibacterial impact occurred, but a very strong antifungal effect was obtained. This effect reflects that the temperature stimulus cannot convert PDMAEMA into its quaternary ammonium salt PD$\mathrm{MAEMA}^{+}$(which is the key point for bacteria-killing), however, this stimulus can release the loaded anidulafungin extremely which inhibited the growth of the yeast considerably (entry 3 in Table 2). Bubbling with $\mathrm{CO}_{2}$ gas at this elevated temperature reduced the loaded cargo a little bit to a strong inhibition growth of $C$. albicans and further this effect converted PDMAEMA to PDMAE$\mathrm{MA}^{+}$with strong inhibition too for $E$. coli growth (entry 4 in Table 2). It is clear that the most important steps for antifungal and antibacterial effects were for pure temperature stimulus and pure $\mathrm{CO}_{2}$ stimulus, respectively. Using both stimuli together is also effective against the two microbes, but it is not powerful like using the individual stimulus alone.

Table 2. The cytotoxicity effect of each stimulus on two selected microbial strains $E$. coli and C. albicans which symbolized by +: weak,

++ : medium, +++: strong and ++++: very strong.

\begin{tabular}{lcc}
\hline & \multicolumn{2}{c}{ Antimicrobial activity on } \\
Stimuli Type & E. coli (Bacteria) & C. albicans (Yeast) \\
\hline $25^{\circ} \mathrm{C}$ & $\mathrm{NA}$ & + \\
$25^{\circ} \mathrm{C}+\mathrm{CO}_{2}$ & ++++ & ++ \\
$45^{\circ} \mathrm{C}$ & $\mathrm{NA}$ & ++++ \\
$45^{\circ} \mathrm{C}+\mathrm{CO}_{2}$ & +++ & +++ \\
\hline
\end{tabular}

\section{Conclusions}

In this article, a temperature- and $\mathrm{CO}_{2}$-sensitive delivery system composed of grafted copolymer capped MSN was explained. A poly(DMAEMA)-co-poly(MPS) shell on MSN was constructed via a facile one-step reaction (condensation \& polymerization) and characterized successfully. The grafted copolymer showed both temperature- and $\mathrm{CO}_{2}$-sensitive release properties for the antifungal anidulafungin drug, which then confirmed by killing C. albicans yeast, with low to moderate results (high in some cases). Most importantly, the PDMAEMA coating can kill E. coli bacteria effectively upon converting to its cationic form through $\mathrm{CO}_{2}$ responses. This novel strategy of designing dual-responses via particles-coating followed by evaluating the biological activity can inspire the engineering of advanced bionanomaterials.

\section{Acknowledgments}

This work was supported by the National Natural Science Foundation of China (No. 21871069) and Open Project of Key Laboratory of Microsystems and Microstructures Manufacturing (2016KM003).

\section{Notes}

The authors declare no competing financial interest.

\section{References}

1. P.Zhou, L. Wang, G. Wu, Y.Zhou, M. Hegazy, X. Huang, ChemistrySelect 2017, 2, 6249-6253. DOI:10.1002/slct.201701339

2. G. Wu, X. Liu, P. Zhou, L. Wang, M. Hegazy, X. Huang, Y. Huang, Mater. Sci. Eng. C 2018, 94, 524-533.

DOI:10.1016/j.msec.2018.09.061

3. N. Rahoui, M. Hegazy, B. Jiang, N. Taloub, Y. D. Huang, Am. J. Anal. Chem. 2018, 9, 273-285. DOI:10.4236/ajac.2018.95021

4. N. Rahoui, P. Zhou, N. Taloub, M. Hegazy, Y. D. Huang, IOP Conf. Ser.: Mater. Sci. Eng. 2018, 389, 012009.

DOI:10.1088/1757-899X/389/1/012009

5. N. Taloub, L. Liu, N. Rahoui, M. Hegazy, Y. Huang, Polym. Test. 2019, 75, 344-349.

DOI:10.1016/j.polymertesting.2019.02.016

6. N. Taloub, A. Henniche, L. Liu, J. Li, N. Rahoui, M. Hegazy, Y. Huang, Comp. Part B: Eng. 2019, 163, 260-271.

DOI:10.1016/j.compositesb.2018.11.007

7. M. Hegazy, P. Zhou, G. Wu, L. Wang, N. Rahoui, N. Taloub, X. Huang, Y. Huang, Polym. Chem. 2017, 8, 5852-5864. DOI:10.1039/C7PY01179B

8. W. Fan, X. Tong, F. Farnia, B. Yu, Y. Zhao, Chem. Mater. 2017, 29, 5693-5701. DOI:10.1021/acs.chemmater.7b01656

9. X. Tang, X. Liang, L. Gao, X. Fan, Q. Zhou, J. Polym. Sci. Part A: Polym. Chem. 2010, 48, 2564-2570.

DOI:10.1002/pola.24034 
10. P. Zhou, S. Wu, X. Liu, M. Hegazy, G. Wu, X. Huang, ACS Appl. Mater. Interfaces 2018, 10, 38565-38573.

DOI:10.1021/acsami.8b11216

11. G. Wu, X. Liu, P. Zhou, Z. Xu, M. Hegazy, X. Huang, Y. Huang, Mater. Sci. Eng. C 2019, 99, 1153-1163.

DOI:10.1016/j.msec.2019.02.069

12. Y. Xue, H. Xiao, Y. Zhang, Int. J. Mol. Sci. 2015, 16, 3626-3655. DOI:10.3390/ijms16023626

13. S. El-Hamouly, M. Azab, M. Hegazy et al., Asian J. Chem. 2012, 24, 176-180.

14. P. Zhou, S. Wu, M. Hegazy, H. Li, X. Xu, H. Lu, Xin Huang, Mater. Sci. Eng. C 2019, 104, 109914.

DOI:10.1016/j.msec.2019.109914

15. M. Hegazy, N. Rahoui, A. A. Elyazed, D. E. Fouad, Xin Huang, Yudong Huang, Polym. Korea 2019, 43, 387-393.

DOI:10.7317/pk.2019.43.3.387

16. N. Rahoui, B. Jiang, N. Taloub, M. Hegazy, Y. D. Huang, J. Biomater. Sci., Polym. Ed. 2018, 29, 1482-1497.

DOI:10.1080/09205063.2018.1466470

17. N. Longkumer, K. Richa, R. Karmaker, V. Kuotsu, A. Supong, L. Jamir, P. Bharali, U. B. Sinha, Acta Chim. Slov. 2019, 66, 276-283. DOI:10.17344/acsi.2018.4580

18. M. Hegazy, S. El-Hamouly, M. Azab, S. Beshir, M. Zayed, Polym. Sci. Ser. B 2014, 56, 182-190.

DOI:10.1134/S1560090414020067
19. A. Vasile, M. Ignat, M. F. Zaltariov, L. Sacarescu, I. Stoleriu, D. Draganescu, M. Dumitras, Lacramioara Ochiuz, Acta Chim. Slov. 2018, 65, 97-107. DOI:10.17344/acsi.2017.3641

20. N. Rahoui, B. Jiang, M. Hegazy, N. Taloub, Y. Wang, M. Yu, Y. D. Huang, Colloids Surf. B: Biointerf. 2018, 171, 176-185. DOI:10.1016/j.colsurfb.2018.07.015

21. M. Hegazy, P. Zhou, N. Rahoui, G. Wu, N. Taloub, Y. Lin, X. Huang, Y. Huang, Colloids Surf. A: Physicochem. Eng. Asp. 2019, 581, 123797. DOI:10.1016/j.colsurfa.2019.123797

22. Z. Dong, J. Mao, D. Wang, M. Yang, X. Ji, Langmuir 2015, 31, 8930-8939. DOI:10.1021/acs.langmuir.5b02159

23. L. Ma, R. Liu, J. Tan, D. Wang, X. Jin, H. Kang, M. Wu, Y. Huang, Langmuir 2010, 26(11), 8697-8703.

DOI:10.1021/la904431z

24. F. A. Plamper, M. Ruppel, A. Schmalz, O. Borisov, M. Ballauff, A. H. E. Muller, Macromolecules 2007, 40, 8361. DOI:10.1021/ma071203b

25. H. Che, M. Huo, L. Peng, Q. Ye, J. Guo, K. Wang, Y. Wei, J. Yuan, Polym. Chem. 2015, 6, 2319-2326. DOI:10.1039/C4PY01800A

26. H. Zou, W. Yuan, Polym. Chem. 2015, 6, 2457-2465. DOI:10.1039/C5PY00024F

27. B. Wang, Q. Xu, Z. Ye, H. Liu, Q. Lin, K. Nan, Y. Li, Y. Wang, L. Qi, H. Chen, ACS Appl. Mater. Interfaces 2016, 8, 2720727217. DOI:10.1021/acsami.6b08893

\section{Povzetek}

Anorganske strukture funkcionalizirane s polimeri imajo pomembno vlogo na različnih bioloških področjih. V tej raziskavi smo z enostopenjsko reakcijo sintetizirali dvojno odziven nanomaterial, pripravljen iz mezoporozne silike na katero smo graftirali dva okoljsko-odzivna polimera: poli (3-metakriloksipropiltrimetoksilan) "PMPS" in poli(N,N-dimetilaminoetil metakrilat) "PDMAEMA". Pripravljen material smo karakterizirali z BET in BJH tehnikami, da smo določili velikost por, volumen por in specifično površino. PDMAEMA je deloval kot aktivno stikalo, ki je določalo nalaganje oziroma in-vitro sproščanje protiglivičnega zdravila adsorbiranega v mezoporah materiala, glede na spremembe $\mathrm{v}$ temperature oziroma $\mathrm{CO}_{2}$ koncentracije okolice. Če smo sintetiziran material izpostavili $\mathrm{CO}_{2}$ atmosferi za nekaj minut, se je s tehniko difuzije na disku pokazal obetajoč bakteriocidni učinek. V splošnem smo pokazali pozitiven učinek proti nekaterim bakterijskim sevom in glivam kar nakazuje možnost, da bi lahko sintetizirani delci pripomogli k načrtovanju bolj učinkovitih protiglivičnih in protibakterijskih učinkovin za farmacevtske aplikacije.

Except when otherwise noted, articles in this journal are published under the terms and conditions of the Creative Commons Attribution 4.0 International License 